\title{
Pengaruh Beban Kerja dan Mutasi Terhadap Semangat Kerja Dengan Kompetensi Sebagai Variabel Intervening pada Ditreskrimum Polda Riau
}

\author{
Novemaril, Susi Hendriani, Yulia Efni \\ Program Studi Magister Manajemen Universitas Riau \\ email: pepen.binkar@gmail.com
}

\begin{abstract}
Abstrak
Artikel INFO

Diterima:06 Februari 2018 Direvisi :10 April 2018 Disetujui: 24 Mei 2019

DOI: http://dx.doi.org/10.24014/ jp.v14i2.4609

Semangat kerja merupakan hal yang penting bekerja. Beberapa penelitian menunukkan bahwa semangat kerja dapat dipengaruhi oleh beban kerja, mutasi dan kompetensi. Penelitian ini bertujuan untuk menguji pengaruh beban kerja dan mutasi terhadap semangat kerja dengan kompetensi sebagai variabel intervening. Pengumpulan data penelitian dengan menggunakan kuestioner. Responden penelitian sebanyak 134 orang Personil ditreskrimum Polda Riau. Analisis data dengan menggunakan pendekatan Deskriptif dan Partial Least Square. Hasil penelitian menemukan bahwa beban kerja tidak berpengaruh signifikan terhadap semangat kerja secara langsung, namun akan berpengaruh apabila disertai kompetensi sebagai variabel intervening. Hasil Penelitian juga menunjukkan bahwa mutasi kerja berpengaruh signifikan terhadap semangat kerja baik secara langsung maupun dengan variabel kompetensi sebagai variabel intervening. kesimpulan penelitian adalah bahwa beban keja, mutasi dan kompetensi berperan dalam meningkatkan atau menurunkan semangat kerja anggota polisi bagian ditreskrimum Polda Riau.
\end{abstract}

Kata Kunci : Beban Kerja, Mutasi, Semangat Kerja, Kompetensi,

\section{The Effect of Workload and Mutation on Morale with Competence as Intervening Variable on Ditreskrimum Riau Police}

\begin{abstract}
Work Morale is an important thing in working. Some studies show that work morale can be influenced by workload, mutations and competencies. This study aims to examine the effect of workload and mutation on morale and competence as intervening variables. The data collection using questioner. The research respondents were 134 Personnels at the ditreskrimum Polda Riau. Data analysis using descriptive and Partial Least Square approach. The results of the study found that workload did not have a significant effect on direct morale, but would have an effect if accompanied by competence as an intervening variable. Research results also show that work mutations have a significant effect on work morale both directly and with competency variables as intervening variables. The conclusion of the study was that workload, mutation and competence were play an important role in increasing or decreasing the work morale of the police officers.
\end{abstract}

KeyWords :Work Load, Placement, Work Morale, Competency 


\section{Pendahuluan}

Sumber daya manusia merupakan faktor utama dan penentu keberhasilan suatu organisasi. Organisasi dituntut untuk meningkatkan kualitas sumber daya manusia yang proaktif terhadap perubahan. Seiring dengan terjadinya Reformasi tahun 1998, maka Polri telah melakukan reformasi sejak tahun 1999 dengan diterbitkannya buku biru Polri yang membahas 3 (tiga) aspek fundamental perubahan yaitu : Instrumental; Struktural; dan Kultural. Perubahan diawali pada aspek Intrumental dengan adanya Undang-Undang Nomor 2 tahun 2002 tentang Kepolisian Negara Republik Indonesia. Dalam rangka mendorong kesuksesan dan keberhasilan proses Reformasi Birokrasi Polri. Sasaran yang paling penting dari ketiga aspek adalah spek kultural yakni perubahan budaya, budaya dari budaya militeristik menjadi Polri sipil yang mampu berbaur dengan masyarakat sesuai dengan rel yang seharusnya. Perubahan budaya dengan sasaran perubahan pola pikir (mind set) dan perubahan budaya kerja (cultur set).

Seiring dengan itu pemerintah telah mengeluarkan Peraturan Menteri Negara Pendayagunaan Aparatur Negara nomor : PER/ 15/M.PAN/7/2008 tanggal $10 \mathrm{Juli}$ 2008 tentang Pedoman Umum Reformasi Birokrasi. Reformasi birokrasi menurut Sedarmayanti (2009:71) adalah upaya pemerintah meningkatkan kinerja melalui berbagai cara dengan tujuan efektivitas, efisien dan akuntabilitas. Pelaksanaan Reformasi Birokrasi Polri yang dilaksanakan saat ini berpedoman kepada Undang-Undang nomor 17 tahun 2007 tentang rencana pembangunan jangka panjang nasional tahun 2005 - 2025. Kemudian Kepala Kepolisian Republik Indonesia menindaklanjuti dengan mengeluarkan keputusan Kepala Kepolisian Republik Indonesia No. Pol. : Kep/37//X/2008 tanggal 27 oktober 2008 tentang program kerja akselerasi transformasi Polri menuju Polri yang mandiri, profesional dan dipercaya masyarakat. Polri dalam hal ini Kepala Kepolisian Republik Indonesia memutuskan untuk mengkonversikan dan mengintegrasi program Transformasi Polri kedalam program reformasi Birokrasi Nasional Program Transformasi Polriyang telah dihasilkan adalah dikeluarkannya Undang-Undang nomor 2 tahun 2002 tentang Polri yang merumuskan perubahan paradigma kepolisian dengan harapan dapat memantapkan kedudukan, peranan serta pelaksanaan tugas Polri dan menetapkan bahwa Polri tidak lagi berada dibawah Angkatan Bersenjata Republik Indonesia (ABRI).

Sehubungan dengan adanya transpormasi tersebut, maka Polri dituntut untuk memiliki kinerja yang tinggi. Kinerja adalah hasil kerja seorang pegawai baik berupa produk atau jasa berdasarkan kualitas, kuantitas, dan waktu penyelesaian pekerjaan. Untuk mengetahui kinerja yang telah dicapai oleh pegawai, semua organisasi atau perusahaan mutlak harus melaksanakan penilaian kinerja, yaitu dengan membandingkan hasil kerja aktual pegawai dengan standar-standar yang telah ditetapkan oleh instansi.

Pada Polda Riau, bagian Ditreskrim terbagi menjadi 3 yaitu Ditreskrimum, Ditreskrimsus, dan Ditresnarkoba. Penelitian ini dilakukan di Polda Riau (Kepolisian Daerah Provinsi Riau) pada satker Ditreskrimum. Luasnya ruang lingkup Ditreskrim Polda Riau, maka dalam penelitian ini dibatasi hanya meneliti pada satker Ditreskrimum Polda Riau. Ditreskrimum merupakan unsur pelaksana tugas pokok yang berada di bawah Kapolda, dan dalam pelaksanaan tugas sehari-hari di bawah kendali Wakapolda, yang bertugas menyelenggarakan penyelidikan, penyidikan, dan pengawasan penyidikan tindak pidana umum, termasuk fungsi identifikasi dan laboratorium forensik lapangan.

Untuk melaksanakan tugas dan fungsi Ditreskrimum, maka dibutuhkan semangat kerja personil kepolisian yang tinggi. Semangat kerja adalah melakukan pekerjaan secara lebih giat sehingga pekerjaan dapat diharapkan lebih cepat dan lebih baik. Personil kepolisian sebagai abdi masyarakat yang menjaga keamanan, menegakkan hukum, memberikan perlindungan, pengayoman, dan pelayanan kepada masyarakat perlu memiliki 
semangat kerja yang tinggi agar pelaksanaan tugas dapat terwujud secara profesional, modern dan terpercaya.

Dalam memperhatikan semangat kerja personil kepolisian, perlu diperhatikan faktorfaktor yang mempengaruhinya diantaranya adalah kompetensi, mutasi dan beban kerja.

Kompetensi merupakan kemampuan dan karakteristik yang dimiliki oleh individu personel Polri berupa pengetahuan, keterampilan dan sikap perilaku yang diperlukan dalam pelaksanaaan tugas jabatannya secara profesional, efektif dan efisien. Kompetensi menunjukkan sebagai karakteristik dasar yang dimiliki oleh seorang individu yang berhubungan secara kausal dalam memenuhi kriteria yang diperlukan dalam menduduki suatu jabatan. Kompetensi terdiri dari 5 tipe karakteristik, yaitu motif (kemauan konsisten sekaligus menjadi sebab dari tindakan), faktor bawaan (karakter dan respon yang konsisten), konsep diri (gambaran diri), pengetahuan (informasi dalam bidang tertentu) dan keterampilan (kemampuan untuk melaksanakan tugas).

Selain kompetensi, mutasi dapat mempengaruhi semangat kerja. mutasi merupakan kegiatan ketenagakerjaan yang berhubungan dengan proses pemindahan fungsi, tanggung jawab dan status ketenagakerjaan tenaga kerja ke situasi tertentu dengan tujuan agar tenaga kerja yang bersangkutan memperoleh kepuasan kerja yang mendalam dan dapat memberikan prestasi kerja yang semaksimal mungkin kepada organisasi.

Kemudian beban kerja dapat mempengaruhi semangat kerja. Beban kerja sebagai personil kepolisian juga perlu dipertimbangkan dalam meningkatkan komitmen organisasi dan meningkatkan semangat kerja. Beban kerja merupakan salah satu aspek yang harus di perhatikan oleh setiap organisasi, karena beban kerja salah satu yang dapat mempengaruhi semangat kerja. Teknik analisis beban kerja (workload analysis) memerlukan penggunaan rasio atau pedoman staf standar untuk menentukan kebutuhan personalia. Analisis beban kerja mengidentifikasi baik jumlah personil kepolisian maupun tugasnya yang diperlukan dalam mencapai tujuan organisasional. Semakin baik beban kerja, maka komitmen organisasi akan meningkatkan dan semangat kerja personil kepolisian juga meningkat.

Hasil penelitian yang dilakukan sebelumnya yang dilakukan Runtuwene et al (2016), Ayu(2014), Vulandari (2016). Hardy (2009), Engeelbrecht (2016), Linge (2013) dan Sastra (2017) yang menyatakan bahwa dengan adanya beban kerja yang efektif yang diberikan pada tiap individu akan memberikan pengaruh yang signfikan dan akan cenderung untuk dapat meningkatkan semangat kerja individu para pegawai.

Sehubungan dengan semangat kerja yang menurun dipengaruhi berbagai faktor. Semangat kerja dapat dilihat dari beberapa indikasi yaitu : 1) Disiplin kerja, 2) Kinerja baik, 3) Tanggung jawab, 4) Produktifitas kerja meningkat. Akibat banyaknya tindak pidana umum yang masuk dan menjadi tanggung jawab Ditreskrimum untuk melakukan penyidikan menyebabkan konsentrasi kerja personil kepolisian menjadi tidak fokus sehingga menyebabkan penyidikan tidak selesai sesuai dengan waktu yang ditentukan.

Selanjutnya masalah kompetensi yang dapat menyebabkan penurunan semangat kerja. Kompetensi dalam penelitian ini ditetapkan indikatornya yaitu : 1) Berfikir analitis, 2) Berfikir konseptual, 3) Berfikir strategi, 4) Kemampuan membangun hubungan, 5) Prestasi.

Sehubungan dengan kompetensi Personil Kepolisian Ditreskrimum Polda Riau berpedoman pada Pasal 10 Peraturan Kepala Kepolisian Negara Republik Indonesia Nomor 1 Tahun 2012 tentang Rekrutmen dan Seleksi Penyidik Kepolisian Negara Republik Indonesia (Perkapolri Nomor 1/2012) yang berbunyi: Persyaratan calon peserta Rekrutmen dan Seleksi Penyidik Polri.

Pelaksanaan mutasi jabatan yang diterapkan oleh Polda Riau dapat diartikan sebagai perpindahan jabatan Polri sebagai bentuk pengembangan, pembinaan, dan pengayaan pengalaman Polri. Hal demikian sebenarnya hanya diberikan kepada Polri 
tertentu yang memiliki prestasi kerja yang dinilainya cukup baik. Mutasi dalam penelitian ini ditetapkan dengan indikator Peningkatan kewajiban, Hak, Status, dan Penghasilan.

Sedangkan pada pengaruh mutasi terhadap semangat kerja, hasil penelitian Ambarita dan Ridho (2015), dan Sari Dwi Endah (2011) menyatakan bahwa mutasi berpengaruh positif dan signifikan terhadap semangat kerja pegawai, dan hal tersebut sejalan dengan Perkap No 16 Tahun 2012 tentang Mutasi Anggota Kepolisian Republik Indonesia yang menyatakan mutasi adalah bentuk kegiatan pemindahan personel Polri dari suatu jabatan ke jabatan lain, atau antar daerah dengan tujuan untuk pembinaan dan pengembangan karier personil, pemberian pengalaman dan wawasan guna peningkatan kompetensi, serta bentuk penyegaran bagi personil dalam rangka meningkatkan motivasi, semangat kerja dan prestasi kerja guna terwujudnya personel polri yang profesional, bermoral dan modern

Penelitian yang dilakukan sebelumnya yang dilakukan di Polda Riau pada penelitian Tejo (2015) menempatkan Semangat Kerja sebagai variabel akibat, dan menduga mutasi dan beban kerja sebagai variabel penyebab menurunnya semangat kerja, serta melakukan penelitian konfirmasi terhadap populasi tujuan penelitian yang berbeda, dimana pada penelitian Tejo (2015) populasi penelitian adalah Bidang Humas Polda Riau, sedangkan pada penelitian ini populasi tujuan adalah Direktorat Reserse dan Kriminal Umum (Ditreskrimum) Polda Riau.

Berdasarkan uraian yang telah disampaikan, penelitian ini bertujuan untuk menguji pengaruh beban kerja dan mutasi terhadap semangat kerja dengan kompetensi sebagaivariabelintervening padaditreskrimum Polda Riau

\section{Semangat Kerja}

Setiap organisasi selalu berusaha agar produktivitas kerja karyawan dapat ditingkatkan. Untuk itu pimpinan perlu mencari cara dan solusi guna menimbulkan semangat kerja para karyawan. Hal itu penting, sebab semangat kerja mencerminkan kesenangan yang mendalam terhadap pekerjaan yang dilakukan sehingga pekerjaan lebih cepat dapat diselesaikan dan hasil yang lebih baik dapat dicapai.

Menurut Denyer (dalam Moekijat, 2003:136), kata semangat (morale) itu mulamula dipergunakan dalam kalangan militer untuk menunjukkan keadaan moral pasukan, akan tetapi sekarang mempunyai arti yang lebih luas dan dapat dirumuskan sebagai sikap bersama para pekerja terhadap satu sama lain, terhadap atasan, terhadap manajemen, atau pekerjaan. Sedangkan Hasibuan (2014) mengatakan semangat kerja sebagai keinginan dan kesungguhan seseorang mengerjakan pekerjaanya dengan baik serta berdisiplin untuk mencapai prestasi kerja yang maksimal.

Dan menurut Sastrohadiwiryo (2002:282) mengatakan semangat kerja dapat diartikan sebagai suatu kondisi mental, atau perilaku individu tenaga kerja dan kelompokkelompok yang menimbulkan kesenangan yang mendalam pada diri tenaga kerja untuk beerja dengan giat dan konsekuen dalam mencapai tujuan yang telah ditetapkan organisasi. Dalam pendapat lain Siagian (2003:57) mengartikan bahwa semangat kerja pegawai menunjukkan sejauh mana pegawai bergairah dalam melakukan tugas dan tanggung jawabnya di dalam organisasi. Menurut beliau, semangat kerja dapat dilihat dari kehadiran, kedisiplinan, ketepatan waktu, target kerja, gairah kerja serta tanggung jawab yang telah diberikan kepada pegawai tersebut

Echols \& Shadily dalam Mukhiyidin (2012)menyatakansemangatkerjamerupakan terjemahan dari kata morale yang artinya moril atau semangat juang. Semangat kerja (work morale) adalah sikap seorang pegawai terhadap pekerjaannya, atasan, dan rekan kerjanya. Semangat kerja sebagai pernyataan psikologi dinyatakan dengan penghargaan melalui kepuasan kerja, kepercayaan dan kemampuan untuk menyelesaikan pekerjaan. 
Sikap individual atau sekelompok pekerja, yang menghasilkan usaha dan disiplin, dapat juga dinyatakan sebagai tingkat pemenuhan seseorang dengan aspek intrinsik dari pekerjaan, seperti keberagaman pekerjaan dan adanya tantangan kerja, kemampuan untuk berkembang, yang diimplementasikan melalui kecukupan gaji, keamanan kerja, kesehatan dan keselamatan kerja.

Tingkat semangat kerja yang tinggi dapat diartikan dengan kepuasaan kerja, kemauan untuk berusaha, kemampuan untuk berinisiatif, dan komitmen terhadap organisasi dan fokus dalam pencapaian kerja daripada pencapaian pribadi. Sebaliknya tingkat semangat kerja yang rendah diindikasikan dengan tingginya turnover, tingginya harapan terhadap pekerjaan, tidak dapat diselesaikan komplain dan tantangan, dan menurunnya kinerja perusahaan. (Tiwari: 2014)

Definisi-definisi di atas, dapat disimpulkan bahwa semangat kerja adalah keinginan dan kesungguhan seseorang dalam melakukan pekerjaan secara giat dan baik serta berdisiplin tinggi untuk mencapai prestasi kerja yang maksimal. Jadi semangat kerja merupakan salah satu faktor terpenting yang harus diperhatikan oleh pimpinan organisasi, sebab menyangkut masalah kejiwaan para pegawai untuk mau berusaha lebih baik guna mencapai tujuan organisasi. Maka dari itu, didalam mengelola pegawai dalam organisasi harus diciptakan suatu komunikasi kerja yang baik antara pimpinan dan bawahan agar tercipta suatu komunikasi kerja yang serasi dan selaras. Dengan meningkatnya semangat kerja para pegawai tersebut diharapkan akan mencapai kinerja yang lebih baik dibidang pekerjaan mereka masing-masing sehingga akan tercapai pula tujuan organisasi.

Nitisemito (2001), mengemukakan beberapa cara untuk meningkatkan semangat kerja. Diantaranya adalah 1) Gaji yang cukup, 2) Memperhatikan kebutuhan rohani, 3) Harga diri perlu mendapat perhatian, 4) Tempatkan karyawan pada posisi yang tepat, 5) Berikan kesempatan kepada karyawan untuk maju, 6) Perasaan aman menghadapi masa depan perlu diperhatikan, 7) Usahakan para karyawan mempunyai loyalitas, 8) Sekali- sekali para karyawan perlu diajak berunding, 9) Pemberian insentif yang terarah, 10) Fasilitas yang menyenangkan.

Semangat kerja menggambarkan keseluruhan suasana yang dirasakan para karyawan. Apabila karyawan merasa bergairah, bahagia, optimis maka kondisi tersebut menggambarkan bahwa karyawan tersebut mempunyai semangat kerja yang tinggi tetapi apabila karyawan suka membantah, menyakiti hati, kelihatan tidak tenang maka karyawan tersebut mempunyai semangat kerja yang rendah.

\section{Kompetensi}

Kompetensi pada umumnya digambarkan sebagai kemampuan individu dalam suatu organisasi. Menurut Hutapea (2008: 65) atas dasar tingkat kesadaran dalam melakukan pekerjaan, secara awam kita dapat membedakan arti kata kompetensi menjadi:

1. Unconcius incopetence

Apabila seseorang tidak menyadari bahwa dia tidak mampu melakukan sesuatu.

\section{Conscious incompetence}

Apabila seseorang menyadari bahwa dia tidak mampu meelakukan sesuatu.

\section{Conscious Competence}

Apabila seseorang mampu mengerjakan sesuatu dengan tingkat kehati-hatian yang tinggi.

\section{Unconscious Competence}

Apabila seseorang mampu mengerjakan sesuatu dengan mahir sehingga dapat melakukan secara otomatis.

Menurut McClelland (dalam Rivai, 2011) mendefenisikan kompetensi (competency) sebagai jarak teristik yang mendasar yang dimiliki seseorang yang berpengaruh langsung terhadap, atau dapat memprediksikan, kinerja yang sangat baik. Dengan kata lain, kompetensi adalah apa yang para outstanding performers lakukan lebih sering pada lebih banyak situasi dengan hasil yang lebih baik, daripada apa yang dilakukan para average performers.

Kompetensi adalah suatu kemampuan untuk melaksanakan atau melakukan sesuatu pekerjaan atau tugas yang dilandasi atas keterampilan dan pengetahuan serta didukung oleh sikap kerja yang dituntut oleh pekerjaan 
tersebut (Wibowo, 2008: 324).

Menurut Peraturan Kapolri Nomor 05 Tahun 2016 tentang Penyelenggaraan Assessment Center Kepolisian Negara Republik Indonesia, menyebutkan pengertian kompetensi adalah kemampuan dan karakteristik yang dimilikioleh individu personel Polri berupa pengetahuan, keterampilan dan sikap perilaku yang diperlukan dalam pelaksanaaan tugas jabatannya secara profesional, efektif dan efisien.

Dari beberapa defenisi yang disebutkan diatas, kompetensi merupakan suatu kemampuan untuk melakukan suatu pekerjaan dimana kinerja yang dihasilkan pekerja berkompetensi lebih baik dari pekerja rata-rata.

Menurut Michael (2000: 56-58) mengungkapkan bahwa terdapat beberapa faktor yang dapat mempengaruhi kecakapan kompetensi seseorang, yaitu : 1) keyakinan dan nilai-nilai, 2) keterampilan, 3) pengalaman, 4) karakteristik kepribadian, 5) motivasi, 6) isu emosional, 7) kemampuan intelektual dan 8) budaya organisasi.

\section{Indikator Kompetensi}

Kompetensi merupakan hal yang dapat diukur melalui beberapa teknik yang ada. Beberapa teknik yang dapat dipergunakan untuk mengukur kompetensi (Rivai, 2011:309) : 1) Behaviour Event Intervies (BEI), 2) Tes (misalnya work-sampel test, mental ability test, dan personality test)

Dengan adanya beberapa metode untuk mengukur kompetensi diharapkan mampu menciptakan penilaian kompetensi yang sesuai dengan tujuan organisasi, instansi ataupun perusahaan. Dalam mengukur kompetensi seseorang kita perlu mengetahui apa saja indikator dari kompetensi. Pada umumnya indikator kompetensi dilihat dari tiga aspek yakni kognitif, afektif dan psikomotorik.

Menurut Spenser dalam (Hutapea, 2008) mengungkapkan bahwa ada tiga komponen utama pembentuk kompetensi, yaitu pengetahuan yang dimiliki seseorang, keterampilan, dan perilaku individu, yang mana ketiga komponen tersebut dipengaruhi oleh konsep diri, sifat bawaan diri (trait) dan motif.

Sehubungan dengan konsep teori di atas, indikator Kompetensi dalam penelitian ini diambil dari Peraturan Kapolri Nomor 5 Tahun 2016 yaitu: 1) Berpikir analitis (kemampuan berpikir secara sistematis), 2) Berpikir konseptual (kemampuan untuk mengenali pola hubungan dari berbagai kondisi), 3) Berpikir strategik, 4) Kemampuan membangun hubungan (upaya untuk membina, menjaga dan mendayagunakan hubungan atau jaringan kontak yang luas, 5) Semangat berprestasi( kemampuan untuk selalu meningkatkan kinerja dengan lebih baik diatas standar secara terus menerus).

\section{Mutasi}

Menurut Sastrohadiwiryo (2002), menjelaskan bahwa mutasi merupakan kegiatan ketenagakerjaan yang berhubungan dengan proses pemindahan fungsi, tanggung jawab dan status ketenagakerjaan tenaga kerja ke situasi tertentu dengan tujuan agar tenaga kerja yang bersangkutan memperoleh kepuasan kerja yang mendalam dan dapat memberikan prestasi kerja yang semaksimal mungkin kepada organisasi.

Dalam upaya memenuhi kebutuhan sumber daya manusia yang profesional pada setiap satuankerjaKepolisian Negara Republik Indonesia, diperlukan sistem pembinaan karier yang terencana, prosedural, dan konsisten dengan mempertimbangkan keseimbangan kepentingan organisasi dengan pemberian peluang individu, serta menempatkan orang yang tepat pada jabatan yang tepat. Bahwa salah satu sistem pembinaan karier anggota Polri dilaksanakan melalui mutasi pada setiap jenjang kepangkatan secara rutin dan insidentil berdasarkan kebutuhan organisasi atau pertimbangan kepentingan individu anggota sesuai persyaratan yang ditetapkan.

Dalam Peraturan Kepala Kepolisian Negara Republik Indonesia Nomor 16 Tahun 2012 tentang Mutasi Anggota Polri, menjelaskan bahwa mutasi adalah pemindahan anggota dari suatu jabatan ke jabatan lain atau antar daerah. Mutasi jabatan adalah pemindahan anggota dari suatu jabatan ke jabatan yang lain, baik yang 
sifatnya promosi, setara maupun demosi. Sifat mutasi didalam instansi Polri dapat dijelaskan sebagai berikut :

1. Mutasi bersifat promosi, merupakan pengangkatan atau pemindahan anggota yang dilakukan dari satu jabatan ke jabatan lain yang tingkatannya lebih tinggi.

2. Mutasi bersifat setara, merupakan pengangkatan atau pemindahan anggota dari satu jabatan ke jabatan lain yang tingkatannya sejajar.

3. Mutasi bersifat demosi, merupakan pemindahan anggota dari satu jabatan ke jabatan lain yang tingkatannya lebih rendah serta dapat juga diberhentikan dari jabatannya.

Didalam instansi Polri, mutasi merupakan hal yang lumrah dan sering terjadi baik yang dilaksanakan atas kebutuhan organisasi (manajemen) maupun atas keinginan anggota Polri sendiri, umumnya memiliki tujuan yang pasti yakni untuk pembinaan dan pengembangan kualitas anggota Polri agar menjadi lebih bertanggung jawab kepada korps ditempat ia bertugas. Setiap anggota Polri merupakan unsur terpenting dari organisasi kepolisian yang harus dibina dan dikembangkan, namun bagi anggota Polri yang merasa nyaman dengan jabatan dan lingkungan kerjanya mutasi adalah sebuah siksaan, dan sebaliknya mutasi juga merupakan keberkahan bagi sebagian anggota yang memiliki ambisi untuk mendapat tantangan baru atau jabatan baru yang lebih baik. Hakekatnya mutasi adalah bentuk perhatian pimpinan terhadap bawahan atas pertimbangan kepentingan individu anggota dengan tetap mengutamakan kepentingan organisasi.

\section{Beban Kerja}

Beban kerja merupakan salah satu aspek yang harus di perhatikan oleh setiap organisasi, karena beban kerja salah satu yang dapat meningkatkan produktivitas kerja Pegawai.

Sutarto (2006), mengungkapkan bahwa beban kerja adalah aktivitas satuan organisasi atau beban kerja masing-masing pejabat atau pegawai hendaknya merata sehingga dapat dihindarkan adanya satuan organisasi yang terlalu banyak aktivitasnya dan ada satuan organisasi terlalu sedikit aktivitasnya demikian pula dapat dihindarkan adanya pejabat atau pegawai yang terlalu bertumpuk-tumpuk tugasnya dan ada pejabat atau pegawai yang sedikit beban kerjanya sehingga nampak terlalu banyak menganggur

Sedangkan pendapat lain yang menyatakan pendapat beban kerja yang menekankan kepada tuntutan tugas yang harus dikerjakan pegawai adalah menurut Hart dan Staveland dalam (Tarwaka 2011), yang menyatakan bahwa beban kerja merupakan suatu yang muncul dari interaksi antara tuntutan tugas-tugas, lingkungan kerja dimana digunakan sebagai tempat kerja, keterampilan dan persepsi dari pekerja. Beban kerja kadang-kadang didefinsikan secara operasional pada faktor-faktor seperti tuntutan tugas atau upaya-upaya yang dilakukan untuk melakukan pekerjaan. Beban kerja yang harus dilaksanakan pegawai hendaknya merata, sehingga dapat dihindarkan adanya seorang pegawai yang mempunyai beban kerja terlalu banyak atau terlalu sedikit. Namun demikian beban kerja yang merata ini tidak berarti bahwa setiap pegawai dalam organisasi tersebut harus tetap sama beban kerjanya.

Simamora dalam Ayu (2014) menyatakan bahwa Pengukuran waktu kerja pada operasi tempat kerja disebut efisien atau tidak biasanya didasarkan atas lamanya waktu untuk memngerjakan suatu pekerjaan, atau pelayanan. Pernyataan khusus tentang jumlah waktu yang harus digunakan untuk melaksanakan kegiatan tertentu dibawah kondisi kerja normal ini sering disebut tenaga kerja standar. Teknik analisis beban kerja (workload analysis) ini memerlukan penggunaan rasio atau pedoman penyusunan staf standar untuk menentukan kebutuhan pegawai. Analisis beban kerja mengidentifikasi baik jumlah pegawai maupun jenis pegawai yang diperlukan dalam mencapai tujuan organisasi, sedangkan menurut Peraturan Kapolri Nomor 15 tahun 2014 tentang Analisa Beban Kerja dilingkungan Kepolisian Negara Republik Indonesia menyatakan bahwa beban kerja adalah sejumlah target pekerjaan atau 
target hasil pekerjaan yang harus dicapai dalam satu satuan waktu tertentu.

\section{Metode}

\section{Lokasi Penelitian}

Penelitian dilakukan di Polda Riau yang terletak di Jalan Jenderal Sudirman Pekanbaru khususnya pada Ditreskrimum.

\section{Populasi}

Menurut Sulistyo-Basuki (2006 :182) mengemukakan populasi adalah keseluruhan objek yang akan diteliti. Adapun yang menjadi populasi dalam penelitian ini adalah semua Personil Kepolisian di Dit Reskrimum Polda Riau yakni sebanyak 134 orang.

\section{Sampel}

Menurut Sinulingga (2014), sampel adalah bagian dari sebuah populasi yang dianggap dapat mewakili dari populasi tersebut. Karena jumlah Personil Kepolisian Ditreskrimum Polda Riau yang berjumlah 134 pegawai berstatus PNS, maka dalam penelitian ini seluruh populasi dijadikan sampel dengan pengambilan sampel secara sensus.

\section{Prosedur Pengumpulan Data}

Prosedur pengumpulan data dalam penelitian ini diperoleh secara langsung dari sumbernya melalui penyebaran kuesioner, berupa data mutasi dan beban kerja terhadap kompetensi dan semangat kerja. Interval yang digunakan adalah sebagai berikut :

Tabel 1 Interpretasi Hasil pengujian Deskriptif Penelitian

\begin{tabular}{lrl}
\hline No & \multicolumn{1}{c}{ Interval } & \multicolumn{1}{c}{ Kriteria } \\
\hline 1 & $1,00-1,79$ & Tidak Baik \\
2 & $1,80-2,59$ & Kurang Baik \\
3 & $2,60-3,39$ & Cukup Baik \\
4 & $3,40-4,19$ & Baik \\
5 & $4,20-5,00$ & Sangat Baik \\
\hline
\end{tabular}

Sumber : Sinulingga, 2016

\section{Hasil}

Berikut disajikan table yang menguraikan hasil pengukian validitas item pertanyaan dan juga analisis factor penelitian.

\section{Tabel 2 Loading Factor dan Cross} Loading Factor

\begin{tabular}{ccccc}
\hline & Beban & Mutasi & KPTSI & SMGT \\
\hline x11 & $(0.863)$ & 0.745 & 0.687 & 0.673 \\
x12 & $(0.871)$ & 0.649 & 0.656 & 0.560 \\
x13 & $(0.846)$ & 0.693 & 0.669 & 0.669 \\
x21 & 0.666 & $(0.870)$ & 0.663 & 0.643 \\
x22 & 0.753 & $(0.897)$ & 0.691 & 0.655 \\
x23 & 0.716 & $(0.875)$ & 0.622 & 0.787 \\
x24 & 0.641 & $(0.795)$ & 0.624 & 0.619 \\
z1 & 0.640 & 0.585 & $(0.846)$ & 0.694 \\
z2 & 0.542 & 0.530 & $(0.760)$ & 0.477 \\
z3 & 0.615 & 0.579 & $(0.815)$ & 0.610 \\
z4 & 0.741 & 0.713 & $(0.801)$ & 0.832 \\
z5 & 0.572 & 0.615 & $(0.772)$ & 0.567 \\
Y1 & 0.736 & 0.810 & 0.737 & $(0.927)$ \\
Y2 & 0.566 & 0.628 & 0.649 & $(0.899)$ \\
Y3 & 0.664 & 0.706 & 0.725 & $(0.893)$ \\
Y4 & 0.667 & 0.666 & 0.749 & $(0.857)$ \\
\hline
\end{tabular}

Sumber: Data Olahan,2017

Berdasarkan hasil pada tabel 2, dapat disimpulkan bahwa indicator merupakan indicator yang valid. Pada uji Outer Loading (Convergent Validity) akan dinyatakan valid bila nilai loadingnya berada di atas 0,40 , terlihat pada tabel di atas semuua indikator telah valid dikarenakan nilainya berada di atas 0,40.(Sholihin,2013)

Hasil pengujian reliabilitas diuraikan dengan menguraikan nilai pada Composite Reliability (CR), Cronbach Alpha (CA), Average Variable Extracted (AVE).

\section{Tabel 3 Hasil Pengujian Realibilitas}

\begin{tabular}{ccccccc}
\hline No & $\begin{array}{c}\text { Nama } \\
\text { Variabel }\end{array}$ & $\begin{array}{c}\text { Composite } \\
\text { Reliabiliti }\end{array}$ & $\begin{array}{c}\text { Cronbach's } \\
\text { Alpha (CA) }\end{array}$ & AVE & Syarat & $\begin{array}{c}\text { Inter- } \\
\text { pretasi }\end{array}$ \\
\cline { 2 - 6 } 1 & $\begin{array}{l}\text { Beban } \\
\text { Kerja }\end{array}$ & 0.895 & 0.824 & 0.740 & Reliabel \\
2 & Mutasi & 0.919 & 0.882 & 0.740 & $\begin{array}{c}\text { RV } \geq 0,7 \\
\text { CA } \geq 0,7 \\
\text { AVE>0,5 }\end{array}$ & Reliabel \\
3 & $\begin{array}{l}\text { Kompe- } \\
\text { tensi }\end{array}$ & 0.898 & 0.858 & 0.639 & Reliabel \\
4 & $\begin{array}{l}\text { Sema- } \\
\text { ngat } \\
\text { Kerja }\end{array}$ & 0.941 & 0.916 & 0.800 & & Reliabel \\
\hline
\end{tabular}

Sumber : Data Olahan, 2017 
Berdasarkan hasil pada tabel 3, maka dapat disimpulkan bahwa instrumen penelitian telah melewati syarat yang telah dipersyaratkan agar dapat dikatakan reliabel. Dengan demikian instrumen pada penelitian ini telah dianggap reliable.

Setelah hasil menunjukkan model yang dajukan telah sesuai dengan asumsi-asumsi pada pendekatan Partial Least Square, maka hasil pengujian model penelitian disajikan pada grafik berikut :

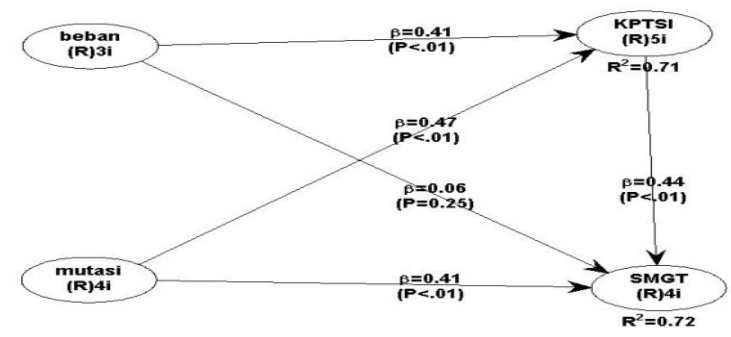

Sumber: Data Olahan, 2017

\section{Grafik 1. Model Penelitian}

\section{Tabel 4 Hasil Pengujian Hipotesis} Penelitian

\begin{tabular}{|c|c|c|c|c|}
\hline \multicolumn{3}{|c|}{ Jenis Variabel } & \multirow{2}{*}{$\begin{array}{c}\text { Penga- } \\
\text { ruh }\end{array}$} & \multirow{2}{*}{$\begin{array}{c}\mathbf{P} \\
\text { Value }\end{array}$} \\
\hline Prediktor & Respon & Mediasi & & \\
\hline Z & Y & & 0,44 & $<0,01$ \\
\hline $\mathrm{X} 1$ & Y & & 0,06 & 0,25 \\
\hline X1 & Y & Z & 0,24 & $<0,01$ \\
\hline $\mathrm{X} 2$ & Y & & 0,41 & $<0,01$ \\
\hline $\mathrm{X} 2$ & Y & Z & 0,619 & $<0,01$ \\
\hline
\end{tabular}

Berdasarkan tabel 4, hasil pengujian hipotesis penelitian dapat diambil kesimpulan sebagai berikut :

1. Hubungan variabel beban kerja terhadap semangat kerja personil Ditreskrimum Polda Riau.

Berdasarkan hasil pada tabel 4, ditemukan hasil penelitian yang menunjukkan bahwa nilai $p$-value hubungan antara variabel beban kerja terhadap semangat kerja sejumlah 0,25. Dimana nilai $p$-value lebih besar daripada nilai toleransi kesalahan penelitian, yaitu 5\%. Dengan demikian berdasarkan hasil penelitian variabel beban kerja berpengaruh tidak signifikan terhadap variabel semangat kerja personil Ditreskrimum Polda Riau.

2. Hubungan variabel mutasi terhadap semangat kerja personil Ditreskrimum Polda Riau.

Berdasarkan hasil pada tabel 4, ditemukan hasil penelitian yang menunjukkan nilai $p$-value hubungan antara variabel mutasi terhadap semangat kerja sejumlah $<0,001$. Berdasarkan hasil tersebut, dimana nilai $p$-value lebih kecil daripada nilai toleransi kesalahan penelitian yaitu 5\%. Maka berdasarkan hasil penelitian, variabel mutasi berpengaruh positif signifikan terhadap variabel semangat kerja personil Ditreskrimum Polda Riau.

3. Hubungan variabel beban kerja terhadap semangat kerja melalui kompetensi personil Ditreskrimum Polda Riau.

Berdasarkan hasil pada tabel 4, ditemukan hasil penelitian yang menunjukkan nilai $p$-value hubungan antara variabel beban kerja terhadap semangat kerja melalui kompetensi sejumlah $<0,01$ atau nilai $p$-value lebih kecil daripada nilai toleransi kesalahan penelitian yaitu $5 \%$. Sehingga dapat dikatakan bahwa variabel beban kerja berpengaruh signifikan terhadap semangat kerja melalui kompetensi sebagai variabel pemediasi.

4. Hubungan variabel mutasi terhadap semangat kerja melalui kompetensi personil Ditreskrimum Polda Riau

Sesuai dengan hasil pada penelitian ini pada tabel 4, ditemukan hasil penelitian yang menunjukkan nilai $p$-value hubungan antara variabel mutasi terhadap semangat kerja melalaui kompetensi sejumlah sejumlah <0,001, maka dapat disimpulkan bahwa variabel mutasi berpengaruh signifikan terhadap variabel semangat kerja melalui kompetensi personil sebagai variabel pemediasi.

5. Hubungan variabel kompetensi terhadap semangat kerja personil Ditreskrimum Polda Riau.

Berdasarkan hasil pada tabel 4, ditemukan 
hasil penelitian yang menunjukkan nilai $p$-value hubungan antara variabel mutasi terhadap semangat kerja sejumlah $<0,001$. Berdasarkan hasil tersebut, dimana nilai $p$-value lebih kecil daripada nilai toleransi kesalahan penelitian, yaitu $5 \%$. Maka dapat disimpulkan variabel kompetensi berpengaruh signifikan terhadap variabel semangat kerja personil Ditreskrimum Polda Riau.

\section{Pembahasan}

Dilihat dari tugas dan fungsinya Ditreskrimum ini memiliki tuntutan kerja, resiko kerja dan beban kerja yang tinggi, menurut peraturan Kapolri Nomor 15 tahun 2014 menyatakan bahwa beban kerja adalah sejumlah target pekerjaan atau target hasil pekerjaan yang harus dicapai dalam satu satuan waktu tertentu, maka untuk mencapai target pekerjaan tersebut tentunya diperlukan semangat kerja yang tinggi dari personil namun hasil dari penelitian ini ditemukan bahwa beban kerja mempunyai pengaruh yang tidak signifikan terhadap semangat kerja personil. Hal ini diperkuat dari hasil deskriptif dimana responden merasa bahwa pekerjaan yang diterima responden sesuai dengan kompetensi yang dimiliki, namun karena pembagian beban kerja yang diterima personil masih belum seimbang antar sesama personil maka mempengaruhi semangat kerja dari personil sehingga mengakibatkan semangat kerja personil belum optimal.

Penelitian ini juga diperkuat dari hasil loading faktor pada variabel beban kerja, dimana ditemukan bahwa indikator yang memiliki kontribusi terbesar adalah indikator kedua yaitu pembagian pekerjaan yang diterima personil, dimana ditemukan responden merasa belum puas dengan pembagian pekerjaan yang diterapkan saat ini karena masih belum seimbangnya pembagian beban kerja. Hal ini dapat mengindikasikan bahwa terdapat personil yang bekerja lebih banyak daripada rata-rata personil, atau juga dapat diartikan terdapat personil yang tidak diberikan penugasan/ pekerjaan secara tepat, sehingga baik bagi personil yang diberikan penugasan berlebih maupun kurang diberikan penugasan dapat mengalami penurunan semangat kerjanya.

Sehubungan dengan pengaruh beban kerja terhadap semangat kerja, penelitian ini bertolak belakang dengan penelitian yang dilakukan oleh Ayu, Desi S (2014), Vulandari (2016). Hardy (2009), Engeelbrecht (2016), Linge (2013) dan Sastra (2017) yang menyatakan bahwa beban kerja berpengaruh signifikan terhadap semangat kerja pegawai.

Menurut Peraturan Kapolri Nomor 16 Tahun 2012, mutasi adalah bentuk kegiatan pemindahan personel Polri dari suatu jabatan ke jabatan lain, atau antar daerah dengan tujuan untuk pembinaan dan pengembangan karier personil, pemberian pengalaman dan wawasan guna peningkatan kompetensi, serta bentuk penyegaran bagi personil dalam rangka meningkatkan motivasi, semangat kerja dan prestasi kerja guna terwujudnya personel polri yang profesional, bermoral dan modern. Namun dalam prakteknya mutasi yang dilakukan di Polda Riau masih belum optimal, hal ini dapat dilihat dari hasil deskriptif dan hasil loading factor penelitian pada variabel mutasi dimana rata-rata tertinggi jawaban responden pada indikator peninjauan hak personil masih belum sesuai dan masih dibawah apa yang diharapkan oleh personil sehingga mempengaruhi semangat kerja personil, atau dapat diartikan mutasi berpengaruh signifikan terhadap semangat kerja personil pada Ditreskrimum Polda Riau.

Hasil penelitian ini sejalan dengan penelitian terdahulu, Ambarita dan Ridho (2015), Lee (2012), Louis (2014), Mensah (2013) serta Runtuwene et al (2016 yang menyatakan bahwa mutasi berpengaruh terhadap semangat kerja.

Beban kerja yang tinggi dapat menyebabkan semangat kerja personil menurun, karena akan menimbulkan stres kerja namun dengan adanya kompetensi yang dimiliki personil diharapkan semangat kerja akan kembali meningkat.

Menurut Peraturan Kapolri Nomor 05 Tahun 2016 menyebutkan pengertian kompetensi adalah kemampuan dan karakteristik yang dimiliki oleh individu 
personel Polri berupa pengetahuan, keterampilan dan sikap perilaku yang diperlukan dalam pelaksanaan tugas jabatannya secara profesional, efektif dan efisien. Personil Ditreskrimum yang memiliki tugas dengan resiko yang tinggi dituntut untuk tetap siap baik secara fisik maupun psikologis dalam menyelesaikan target pekerjaan yang telah dibebankan kepadanya, maka untuk mencapai target pekerjaan tersebut tentunya diperlukan semangat kerja yang tinggi dan kompetensi yang baik. Kompetensi yang dimiliki personel Ditreskrimum, berdasarkan hasil analisa deskriptif dan loading factor menunjukkan rata-rata tertinggi ada pada indikator kemampuan berpikir analitis,. Selain kemampuan analitis yang cukup baik, personil Ditreskrimum juga memiliki kemampuan berfikir konseptual dan strategik yang cukup baik serta mampu menjalin hubungan yang baik dengan berbagai pihak dalam melakukan pekerjaannya. Hal ini sejalan dengan indikator tertinggi pada variabel beban kerja yaitu responden merasa pekerjaan yang diterima personil sesuai dengan kemampuan yang dimiliki. Dengan kompetensi yang dimiliki oleh personil tersebut, maka semakin efisien badan, tenaga, dan pemikirannya dalam melaksanakan pekerjaan, dan tentunya akan mempengaruhi semangat kerja personil walaupun pembagian beban kerja yang diterima oleh personil tidak merata, sehingga dapat dikatakan bahwa beban kerja personil berpengaruh signifikan terhadap semangat kerja personil melalui kompetensi. Hasil penelitian ini sejalan dengan pendapat Rivai, (2011) yang menyatakan bahwa kompetensi (competency) sebagai jarak teristik yang mendasar yang dimiliki seseorang yang berpengaruh langsung terhadap semangat kerja, atau dapat memprediksikan kinerja yang sangat baik.

Dalam proses mutasi personil perlu diperhatikan persyaratan kesesuaian antara minat, bakat, pengetahuan, ketrampilan dan keahlian personil dengan jenis dan tingkat pekerjaan/jabatan yang dipercayakan kepadanya. Dengan kata lain mutasi harus berpegang kepada prinsip "the right man on the right place and the right man on the right job" yang artinya penempatan orangorang yang tepat pada tempat dan untuk jabatan yang tepat sesuai kompetensi yang dimiliki. Seseorang akan bekerja secara berdaya guna dan berhasil guna apabila mengetahui dengan jelas posisinya dalam suatu organisasi kerja. Kejelasan itu sangat penting artinya bagi setiap personil karena memungkinkan mengetahui peranan dan sumbangan pekerjaan terhadap pencapaian tujuan kerja secara keseluruhannya.

Walaupunprosesmutasiyang diterapkan di Polda Riau sudah memperhatikan keseimbangan antara kepentingan pribadi dan organisasi serta berpedoman pada kompetensi yang dimiliki personil, namun oleh responden mutasi yang dilakukan di Polda Riau belum mendapat respon positif dikalangan personil. Hal ini dapat terlihat dari hasil deskriptif dan loading factor pada variabel mutasi dimana rata-rata tertinggi jawaban responden pada indikator peninjauan hak personil, dan ini menunjukkan bahwa responden merasa mutasi yang diterapkan masih belum optimal atau dapat dikatakan bahwa responden merasa mutasi yang dilakukan belum sesuai dan masih dibawah apa yang diexpektasikan walaupun personil memiliki kemampuan kompetensi yang baik dalam melakukan pekerjaan, sehingga akan mempengaruhi semangat kerja personil. Berkaitan hal tersebut dapat diartikan bahwa mutasi berpengaruh signifikan terhdap semangat kerja personil pada Ditreskrimum Polda Riau melalui kompetensi yang dimiliki personil.

Hasil penelitian ini sejalan dengan penelitian terdahulu, Lee (2012) menyatakan bahwa penyebab rendahnya semangat kerja disebabkan oleh rendahnya tingkat kepuasan kerja pekerja yang diakibatkan oleh tidak adanya perkembangan dalam pekerjaan, yang disebabkan oleh strategi mutasi yang dilakukan oleh institusi tidak tepat.

Menurut Peraturan Kapolri Nomor 05 Tahun 2016 menyebutkan pengertian kompetensi adalah kemampuan dan karakteristik yang dimilikioleh individu personel Polri berupa pengetahuan, keterampilan 
dan sikap perilaku yang diperlukan dalam pelaksanaaan tugas jabatannya secara profesional, efektif dan efisien. Personil Polri yang memiliki kompetensi yang baik akan mampu melaksanakan pekerjaan dengan efisien baik badan, tenaga, dan pemikirannya sehingga akan mempengaruhi semangat kerjanya. Semangat kerja adalah keinginan dan kesungguhan seseorang dalam melakukan pekerjaan secara giat dan baik serta berdisiplin tinggi untuk mencapai prestasi kerja yang maksimal. Jadi semangat kerja merupakan salah satu faktor terpenting yang harus diperhatikan oleh pimpinan organisasi, sebab menyangkut masalah kejiwaan para pegawai untuk mau berusaha lebih baik guna mencapai tujuan organisasi.

Berdasarkan hasil deskriptif dan didukung oleh hasil loading factor penelitian di Ditreskrimum Polda Riau didapatkan hasil bahwa personil memiliki kemampuan menganalisa, berfikir strategis dan menjalin hubungan yang baik dengan berbagai pihak. Personil yang memiliki kemampuan / keterampilan yang baik tentunya akan mampu bekerja dengan baik dan semangat yang tinggi walaupun beban kerja yang diterima tidak seimbang dan kurangnya penghargaan yang diberikan pimpinan atas prestasi kerja yang dilakukan. Sehingga dapat diartikan bahwa kompetensi berpengaruh signifikan terhadap semangat kerja. Hal ini sejalan dengan teori Rivai, (2011) yang menyatakan bahwa kompetensi (competency) sebagaijarak teristik yang mendasar yang dimiliki seseorang yang berpengaruh langsung terhadap semangat kerja, atau dapat memprediksikan kinerja yang sangat baik.

\section{Kesimpulan}

Berdasarkan hasil penelitian dan pembahasan, pada penelitian ini beban kerja dilihat dari pembagian tugas dan kompetensi personil dirasa masih ada yang belum sesuai walaupun personil Polri dituntut untuk selalu tetap siap baik secara fisik maupun psikologis dalam menyelesaikan target pekerjaan yang telah dibebankan kepadanya.

Mutasi yang diterapkan di Polda Riau belum mendapat respon yang positif dari personil, karena belum diiringi dengan peninjauan hak dan aktualisasi diri personil.

Personel Ditreskrimum merasa pekerjaan yang diterima sesuai dengan kompetensi yang dimiliki walaupun pekerjaan yang diterima personil masih belum seimbang pembagiannya dengan rekan kerja yang lain.

Pada penelitian ini mutasi melalui kompetensi memiliki dampak nyata dalam meningkatkan semangat kerja personil Ditreskrimum Polda Riau walaupun kenyatannya mutasi yang dilakukan masih belum optimal atau masih belum memperhatikan kualifikasi kompetensi yang dimiliki oleh personil serta belum diiringi dengan peninjauan hak dan aktualisasi diri personil .

Kompetensi memiliki dampak nyata dalam meningkatkan semangat kerja personil. Dalam penelitian ini Kompetensi memiliki dampak nyata dalam meningkatkan semangat kerja personil. Hal ini terlihat dari kemampuan / keterampilan yang dimiliki personil dan rasa tanggung jawab terhadap tugas yang diberikan walaupun beban kerja yang diterima tidak seimbang dan kurangnya penghargaan yang diberikan pimpinan atas prestasi kerja yang dilakukannya

Berdasarkan hasil penelitian, disarankan kepada objek penelitian agar pembagian beban kerja kepada personil hendaknya dibagi secara merata dan disesuaikan dengan kemampuan kompetensi yang dimiliki personel. Proses mutasi personel yang dilakukan hendaknya diiringi dengan peninjauan hak yang menjadi harapan bagi personil. Agar semangat kerja personil dapat terus ditingkatkan selain memperhatikan beban kerja, prosedur mutasi, juga perlu mempersiapkan kompetensi masing-masing personil

Berdasarkan hasil penelitian, ditemukan bahwa variabel mutasi dan beban kerja mempengaruhi sebagian besar terhadap perubahan semangat kerja pada objek penelitian. Sehingga untuk penelitian berikutnya disarankan agar persepsi terhadap variabel menggunakan teknik pengumpulan data yang berbeda, dengan jumlah sampel yang berbeda atau lebih banyak agar dapat 
ditemukan faktor-faktor lainnya, sehingga dapat meningkatkan sumbangsih pengaruh terhadap semangat kerja objek penelitian.

\section{Daftar Pustaka}

Ambarita, Arnimisari J, Ridho, Hatta, (2015), Pengaruh Mutasi terhadap Semangat Kerja Pegawai Negeri Sipil pada Kantor Pelayanan Pajak Pratama Kota Pematang Siantar, Medan : Jurnal Universitas Medan Area Vol.8 No.2

Afrilyan, Bram, (2017), Pengaruh Kompetensi, Pengalaman Kerja dan Penempatan Kerja Terhadap Komitmen Organisasi PT. Wahana Meta Riau di Pekanbaru Faculty of Ecoomics Riau University, Pekanbaru, Indonesia : JOM Fekon, Vol. 4 No. 1

Ayu, Desi S, (2014), Analisis Beban Kerja dan Kebutuhan Pegawai Pada Sekretariat Daerah Kota Bogor, Bogor : Reposistory IPB

Darmawan, Didit, (2008), Variabel Semangat Kerja dan Indikator Pengukurannya, Jurnal Kewirausahaan Vol. 2 No.1

Hardy, Ben, (2009), Morale : Definition, Dimension and Measurement : Trinity Hall, University of Cambridge, 30 September 2009

Hasibuan, Malayu S.P, (2005), Manajemen Sumber Daya Manusia ed. Revisi cetakan 7, Jakarta : Bumi Aksara

Hutapea, Parulian dan Nurianna Thoha. (2008). Kompetensi Plus, Jakarta, PT Gramedia Pustaka Utama

Lee, Chungsup et al, (2012), Low Morale \& Bournout: Causes dan Solution, Urbana Campaign : University of Illinois- Departement of Recreation and Park Resources

Linge, Teresia dan Kiruri, James, (2013), The effect of Placement Practices on Employee Performance in Small Service Firms in Information Technology Sectori in Kenya : United Stated International University : International Journal of Business and Social Science, Vol. 4 No. 15

Louis Joan, et al, (2014), Supervision and
OtherDeterminants of Employee Morale: The Case of Banco de Oro Branches in Batangas City and Bauan, Philiphines : Master in Business Administration, Graduate School, Lyceum of the Philippines University, Batangas City, Philippines, Vol. 2 No. 5

Mensah, Elisabeth BK, dan Tawiah, Kwesi

A, (2016), Employee Motivation and Work Performance : A Comparative Study of Mining Companies in Ghana : University for Development Studies, University of Ghana : Asia Pacific Journal of Multidisciplinary Research : Journal of Industrial Engineering and Management, 2016 - 9(2): 255-309

Moekijat, (2003). Manajemen Sumber Daya Manusia, CV. Mandar Maju, Bandung. Nitisemito, Alex S. (2001). Manajemen Personalia, Ghalia Indonesia, Jakarta.

Novita, Dina (2015), Pengaruh Program Pelatihan, Pengembangan Karyawan dan Budaya Organisasi Terhadap Kompetensi Karyawan PT. Waskita Karya (Persero) Tbk. Cabang Pekanbaru, Pekanbaru : Jurnal Online Mahasiswa, Vol.2 No2.

Patricia Runtuwene, Bernhard Tewal dan Christoffel Mintardjo, (2016), Pengaruh Penempatan Kerja, Mutasi dan Beban Kerja Terhadap Kinerja Karyawan pada PT.Bank Sulutgo Manado, Universitas Sam Ratulangi, Manado : Jurnal Berkala IImiah Efisiensi, Vol 16 No.01.

Republik Indonesia, (2008), Permenpan No 15 tahun 2008 tentang Pedoman Umum Reformasi Birokrasi, Jakarta : Lembaran Negara.

Republik Indonesia, (2007), Undang-undang Republik Indonesia Nomor 17 Tahun 2007 tentang Rencana Pembangunan Jangka Panjang Nasional Tahun 20052025, Jakarta : Lembaran Negara.

Republik Indonesia, (2002), UU Republik Indonesia No.2 tahun 2002 tentang Kepolisian Negara Republik Indonesia, Jakarta : Lembaran Negara.

Republik Indonesia, (2008), Keputusan Kepala Kepolisian Negara Republik Indonesia nomor: Kep/37/IX/2008 tahun 
2008 tentang Program Kerja Akselerasi Tranformasi Polri Menuju Polri Yang Mandiri, Profesional Dan Dipercaya Masyarakat, Jakarta: Lembaran Negara.

Republik Indonesia, (2012), Peraturan Kepala

Kepolisian Negara Republik Indonesia Nomor 16 Tahun 2012 Tentang Mutasi Polri, Jakarta: Lembaran Negara.

Republik Indonesia, (2014), Peraturan Kepala Kepolisian Negara Republik Indonesia Nomor 15 tahun 2014 tentang Analisa Beban Kerja di Lingkungan Kepolisian Negara Republik Indonesia, Jakarta: Lembaran Negara

Republik Indonesia, (2016) Peraturan Kepala Kepolisian Negara Republik Indonesia Nomor 5 Tahun 2016 Tentang Penyelenggaraan Assessment Center Kepolisian Negara Republik Indonesia, Jakarta : Lembaran Negara

Rivai, Veithzal, (2011). Manajemen Sumber Daya Manusia Untuk Perusahaan Dari Teori Ke Praktek : PT. Raja Grafindo Persada, Jakarta.

Sastra Boy, A, (2017), Pengaruh Kompetensi Karyawan dan Beban Kerja terhadap Kinerja Karyawan Bank Danamon Cabang Tuanku Tambusai Pekanbaru, Faculty of Economics, Riau University, Pekanbaru : Jurnal Online Mahasiswa Fekon Vol. 4 No. 1

Sastrohadiwiryo, (2002), Manajemen Tenaga Kerja Indonesia: Pendekatan Adminstratif dan Operasional, Jakarta : Bumi Aksara

Sholihin, Mahfud, (2013), Analisis SEM-PLS dengan WarpPIs 3.0, Yogyakarta : Penerbit Andi

Sinulingga, Sukaria, (2014), Metode Penelitian ed.3, Medan : USU Press

Sugiyono, (2010), Statistika Untuk Penilaian, Bandung : Alfabeta

Sutarto, (2006), Dasar-dasar Kepemimpian Administrasi, Yogyakarta : GMUP Gadjah Mada, University Press

Tarwaka, (2011). Ergonomi untuk Keselamatan Kerja dan Produktivitas. Surakarta: Uniba Press

Tejo, Guntur, A, (2015), Pengaruh Kompetensi dan Budaya Organisasi Terhadap Motivasi Kerja Serta Dampaknya Terhadap Kinerja Personil Bid Humas Polda Riau, Jurnal Tepak Manajemen Bisnis, Vol. VII No.3.

Vulandari, Retno Tri, (2016), Pengaruh Beban Kerja Individu, Beban Kerja Organisasi dan Kepemimpinan terhadap Kinerja Karyawan (Studi Kasus Bank Sinarmas Klaten), Program Studi Sistem Informasi STMIK Sinar Nusantara Surakarta : Journal of Mathematics Education, Science and Technology, Vol. 1 No.2.

Wibowo, (2013), Manajemen Kinerja ed.3, Jakarta, PT. Raja Grafindo Persada.

Yolanda, Yosi, (2017), Pengaruh Kompensasi Non Finansial, Penempatan Kerja dan Kemampuan terhadap Semangat Kerja Karyawan pada PT.Bank Perkreditan Rakyat Unisritrama : JOM Fekon, Vol 4 No.1 